\title{
The Role of Insects and Microorganisms in Plastic Biodegradation: A Comprehensive Review
}

\author{
Sheetal S Kesti ${ }^{1}$, Shivasharana C. T. ${ }^{2 *}$ \\ ${ }^{1,2}$ Department of Studies in Biotechnology and Microbiology, Karnatak University, Pavate nagar, Dharwad, India, 580003. \\ *Corresponding Author: shivaskud@gmail.com Tel.: +919482081120
}

Available online at: www.isroset.org

Received: 07/Dec/2018, Accepted: 21/Dec/2018, Online: 31/Dec/2018

\begin{abstract}
Plastic has been considered as a major environment polluting material for decades. Its physical, chemical and mechanical properties such as high tensile strength, elongation properties, high molecular weight, inertness and hydrophobic nature make it non-biodegradable. In spite of the fact that both environmental and microbial degradation of plastic have been studied in detail, most of the microorganisms reported so far are limited in their functions. However, the recent approaches in plastic degradation by use of insect caterpillars and their gut microbiota have shown interesting results. Plodia interpunctella (Indian meal worms), Tenebrio molitor (Yellow meal worms) and Galleria mellonella (Greater wax worms) are the insects reported till now in plastic degradation. In this comprehensive review, we have briefly focused on the general introduction and classification of plastics and properties which make plastic persistent in the nature. We also have glanced over certain Plastic biodegradation methods reported till today.
\end{abstract}

Keywords - Plastic, Biodegradation, Insects, Persistent, Microbiota.

\section{INTRODUCTION}

In the today's world, plastic is the most vital synthetic product which is being manufactured enormously and used for many purposes. The word 'plastic' is derived from the Greek word "plastikos" which means it can be molded into many shapes [1]. Plasticity during manufacture, which allows it to be cast, pressed, or extruded into a variety of shapes such as films, fibres, plates, tubes, bottles, boxes, and much more. Plastics are mainly derived from petrochemicals and are composed of long chain hydrocarbon polymers with high molecular weights [2]. During the last five to six decades plastics have been used in various applications and have been replaced with leather materials, wood, traditional metals and many more. The most preferred property of plastic is its durability which also exerts the major environmental problem of degradation. Practically, recycling of plastics has failed to provide a safe solution for disposal of plastic waste. United States of America alone produce 1 trillion plastic bags annually among which, only 5\% is being recycled [3]. Basically, plastics are classified based on their thermal and designing properties. Based on thermal properties, plastics are categorized as thermoplastics and thermosetting polymers. Thermoplastics can be molded into any shape upon heating and these include Polyethylene (PE), Polystyrene (PS), Polypropylene (PP), Polyvinyl chloride (PVC), etc. with the molecular weight ranging from 20,000 to 500,000 amu. Thermosetting polymers once set into a definite shape cannot be molded again. These polymers cannot be recycled as their change is irreversible.
Polyurethanes, Phenol-formaldehyde, etc are some of the examples of thermosetting polymers [4]. Designing properties of plastics are based upon their relevance of manufacturing processes, which include electrical conductivity, tensile strength, thermal stability, degradability and durability [4].

\section{Biodegradation of plastic:}

Biodegradation is defined as the degradation and assimilation of polymeric compounds by living organisms and formation of products such as $\mathrm{CO}_{2}, \mathrm{H}_{2} \mathrm{O}, \mathrm{CH}_{4}$ and biomass [6]. In microbial biodegradation of plastics, the bacterial degradation of hydrocarbons is probably the first reported accounts [7] [8]. Biodegradation of plastics such as polyesters, polyhydroxybutyrates (PHB), polylactic acid (PLA), polyvinyl alcohol (PVA), nylon and Polyethylene (PE) has also been reported [2]. Zheng et al. provided a review on thermoset and thermo plastics [10]. Biodegradation of plastics involve both aerobic and anaerobic processes. In aerobic biodegradation, carbondioxide and water are formed as the end products, while in anaerobic process carbon-dioxide, water and methane are produced [11].

\section{Environmental degradation of plastic:}

Environmental degradation includes thermo- and photooxidation followed by biological activity (microorganisms). Various products such as alkanes, alkenes, ketones, aldehydes, carboxylic acids, alcohols, lactones and esters are 
formed when plastic is subjected to thermo- and photooxidation process. When plastic merges with the additives, auto-oxidation is enhanced and molecular weight of the polymer is reduced which makes the microorganisms to degrade the low molecular weight polymer [13].

\begin{tabular}{|c|c|c|c|}
\hline $\begin{array}{l}\text { Plastic } \\
\text { Recycling } \\
\text { Symbol }\end{array}$ & Plastic Name & $\begin{array}{l}\text { Where to Find } \\
\text { This Plastic in } \\
\text { Your Home }\end{array}$ & $\begin{array}{l}\text { This Plastic is } \\
\text { Valued For }\end{array}$ \\
\hline PETE & $\begin{array}{l}\text { Polyethylene } \\
\text { Terephthalate }\end{array}$ & $\begin{array}{c}\text { water and soda } \\
\text { bottles }\end{array}$ & $\begin{array}{c}\text { clarity } \\
\text { strength } \\
\text { impermeability to gas } \\
\text { and moisture }\end{array}$ \\
\hline HDF & $\begin{array}{l}\text { High Density } \\
\text { Polyethylene }\end{array}$ & $\begin{array}{c}\text { milk jugs, grocery } \\
\text { bags and toiletry } \\
\text { bottles }\end{array}$ & $\begin{array}{l}\text { stiffness } \\
\text { strength } \\
\text { resistance to } \\
\text { moisture } \\
\text { permeability to gas }\end{array}$ \\
\hline & Polyvinyl Chloride & $\begin{array}{l}\text { water pipes, blister } \\
\text { packaging for non- } \\
\text { food items }\end{array}$ & $\begin{array}{c}\text { strength } \\
\text { ease of blending with } \\
\text { other materials } \\
\text { versatility }\end{array}$ \\
\hline & $\begin{array}{l}\text { Low-density } \\
\text { Polyethylene }\end{array}$ & $\begin{array}{c}\text { food bags, } \\
\text { squeezable bottles, } \\
\text { cling films, } \\
\text { disposable cups }\end{array}$ & $\begin{array}{c}\text { flexibility } \\
\text { ease of processing } \\
\text { ease of sealing } \\
\text { barrier to moisture }\end{array}$ \\
\hline PP & Polypropylene & $\begin{array}{l}\text { microwaveable } \\
\text { containers, yogurt } \\
\text { cups, disposable } \\
\text { plates / cups }\end{array}$ & $\begin{array}{c}\text { strength } \\
\text { resistance to heat, } \\
\text { chemicals, oils and } \\
\text { moisture }\end{array}$ \\
\hline PS & Polystyrene & $\begin{array}{l}\text { disposable plates, } \\
\text { cups, cutlery, } \\
\text { containers and } \\
\text { packing peanuts }\end{array}$ & $\begin{array}{c}\text { clarity } \\
\text { versatility } \\
\text { molding ease }\end{array}$ \\
\hline OTHER & $\begin{array}{c}\text { Other (often } \\
\text { Polycarbonate or } \\
\text { ABS) }\end{array}$ & $\begin{array}{l}\text { beverage bottles, } \\
\text { CD's, lenses for } \\
\text { glasses, riot shields }\end{array}$ & $\begin{array}{l}\text { properties dependent } \\
\text { upon the mixture of } \\
\text { polymers } \\
\text { may contain BPA }\end{array}$ \\
\hline
\end{tabular}

Figure 1: Commonly used plastics and their applications [5]

\section{Microbial degradation of plastic:}

The curiosities on microbial degradation of plastics emerged when paraffin degradation by several microorganisms was reported [14]. Later on various microorganisms isolated from soil, water and dumping sites were reported [15]. Microbial degradation of plastics is caused mainly by enzymatic activities where the long chain polymer is cleaved into oligomers and monomers and then further metabolized by microbial cells. It may be aerobic or anaerobic metabolism. In aerobic, the end products after degradation are carbon dioxide and water [15], where as in anaerobic metabolism, carbon dioxide, water and methane are the end products [16]. Several microorganisms like bacteria, fungi and microalgae have been reported in plastic degradation.

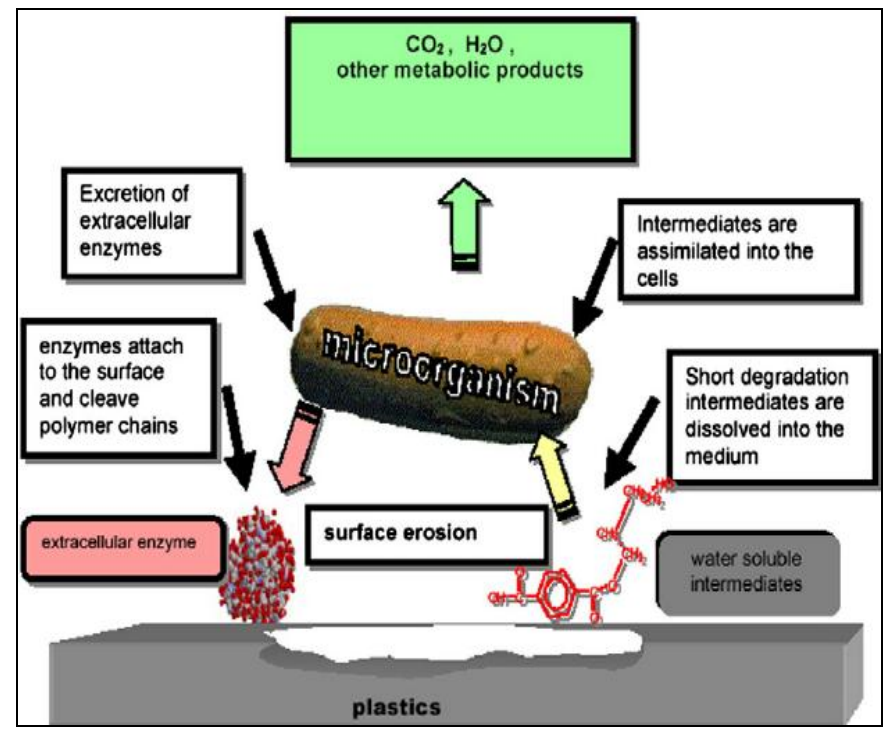

Figure 2: General mechanism of plastic biodegradation [12]

\section{Properties of plastic which makes it non-biodegradable (Persistent):}

High molecular weight, hydrophobicity and complex threedimensional structure makes the plastic recalcitrant for biodegradation. For enzymatic degradation process, melting temperature (Tm) plays a crucial role. Generally, enzymatic activity decreases with increasing time. Higher order structures such as crystalline nature and elasticity suppress the plastic degradation. Furthermore, the additives, stabilizers, physical form of polymer and molecular composition also have an influence on plastic degradation [17].

\section{Mechanisms of plastic biodegradation:}

Biodegradation processes of synthetic plastics have not been understood fully, details of some of them have been known. Biodegradation mechanisms of some of the versatile synthetic polymers such as Polyethylene (PE), Polystyrene (PS) and Polypropylene (PP) have been described below:

\section{Polyethylene (PE):}

$\mathrm{PE}$ is the most common synthetic polymer with $-\mathrm{CH}_{2}-\mathrm{CH}_{2}-$ repeating units as the backbone. The characteristics of $\mathrm{PE}$ which make it resistant to biodegradation are: 1) highly stable C-C and $\mathrm{C}-\mathrm{H}$ covalent bonds, 2) high molecular weight of PE which resist them to penetrate the cell walls of microorganisms, 3) lack of chromophores which act as catalysts for interdependent photo and biodegradation, and 4) highly hydrophobic nature [18]. Several microorganisms, such as Actinobacter, Streptomyces, Aspergillus, Penicillium, and Mucor have been reported till now [4] [19] [20]. 


\section{Polystyrene (PS)}

Polystyrene is a synthetic hydrophobic polymer with high molecular weight. Due to its hydrophobic nature and high molecular weight it is not readily biodegradable. Several strains of Actinomycetes have been reported in PS biodegradation, but the degree of degradation was very low [21]. Numerous species of fungi and bacteria have been reported in PS biodegradation, although the rate of biodegradation was very low, but with the addition of cellulose and minerals the degradation rate was increased [22] [23].

\section{Polypropylene (PP)}

Polypropylene belongs to thermoplastics category which is used in packaging materials, plastic molding, stationery, diapers, etc. In environmental degradation, exposure of PP to ultraviolet radiations and oxidation at high temperatures break down the polymer into simpler molecules and in microbial degradation, several species of fungi and bacteria such as Aspergillus spp., Pseudomonos, E.coli, and Vibrio spp. have been reported [3] [24].

Table 1: List of microorganisms involved in plastic biodegradation.

\begin{tabular}{|c|c|c|c|}
\hline SI. No. & Microorganisms & Type of plastic used & References \\
\hline 1. & Bacillus sp. & Polyurethane & [25] \\
\hline 2. & Pseudomonas aeruginosa & PVC powder & [26] \\
\hline 3. & $\begin{array}{c}\text { Rhodococcus } \\
\text { Rhodocorrous ATCC } \\
29672 \text { and } \\
\text { Nocardia steroids GK911 }\end{array}$ & Degradable polyethylene & [27] \\
\hline 4. & $\begin{array}{l}\text { Streptococcus sp., } \\
\text { Staphylococcus sp., } \\
\text { Micrococcus sp., } \\
\text { Moraxella sp., and } \\
\text { Pseudomonas sp. }\end{array}$ & $\begin{array}{l}\text { Polyethylene bags and } \\
\text { plastic cups }\end{array}$ & [28] \\
\hline 5. & $\begin{array}{c}\text { Pseudomonas sp. (P1, } \mathrm{P} 2 \text {, } \\
\text { and } \mathrm{P} 3)\end{array}$ & $\begin{array}{c}\text { Natural and synthetic } \\
\text { polyethylene }\end{array}$ & [29] \\
\hline 6. & $\begin{array}{c}\text { Bacillus cereus, Bacillus } \\
\text { megaterium, Bacillus } \\
\text { subtilis, and Brevibacillus } \\
\text { borstelensis }\end{array}$ & LDPE and LLDPE & [30] \\
\hline 7. & $\begin{array}{l}\text { Aspergillus flavus and } \\
\text { Mucor rouxii NRRL } 1835\end{array}$ & Disposable plastic films & [31] \\
\hline 8. & $\begin{array}{l}\text { Aureobasidium pullulans, } \\
\text { Rhodotorula aurantiaca, } \\
\text { and Kluyveromyces spp. }\end{array}$ & Plasticized PVC & [32] \\
\hline 9. & $\begin{array}{l}\text { Penicillium pinophilium } \\
\text { and Aspergillus niger }\end{array}$ & $\begin{array}{c}\text { Low density } \\
\text { polyethylene (LDPE) } \\
\text { powder }\end{array}$ & [33] \\
\hline 10. & Fusarium sp. AF4 & LDPE & [34] \\
\hline 11. & Aspergillus spp. & HDPE & [35] \\
\hline
\end{tabular}

\section{Insects:}

Being the most diversified organisms on earth, insects are known to exhibit a wide number of applications which are being explored by humans. Insects like Silkworm, Black soldier fly, Galleria mellonella (Greater wax moth), and many more agriculturally important ones are being highly used in biotechnological research. Among these, a recent approach on plastic degradation by insects has become a fascinating area in environmental plastic pollution issues. The gut microorganisms of Plodia interpunctella, also known as Indian meal worm were able to degrade polyethylene (PE) [36] [37]. Later, the similar study was carried out with Tenebrio molitor (Yellow meal worms) and reported that the meal worms could chew and eat Polystyrene (PS), commonly called as Styrofoam. Polystyrene digestion in yellow meal worms was studied by isotopic tests [38] [39]. Recently, it was also found that the caterpillars of Galleria mellonella, commonly known as Greater wax moth larvae could degrade Polyethylene (PE) at a higher rate compared to Plodia interpunctella and Tenebrio molitor [40].

\section{Insects used in plastic degradation:}

Plodia interpunctella, known as Indian meal worm has been considered as a major pest in agriculture and commonly called as stored grains pest. Indian meal moth larvae have been found to pierce into the plastic bags and damage the food grains. Indian meal worms were able to chew and eat Polyethylene (PE) when they were left in direct contact with PE [36]. Enterobacter asburiae YT1 and Bacillus spp. YP1 were the two prominent microorganisms found in the gut of Plodia interpunctella and responsible for PE degradation [36]. A complete genome of Bacillus spp. YP1 was sequenced and found relevant to PE biodegradation [37].

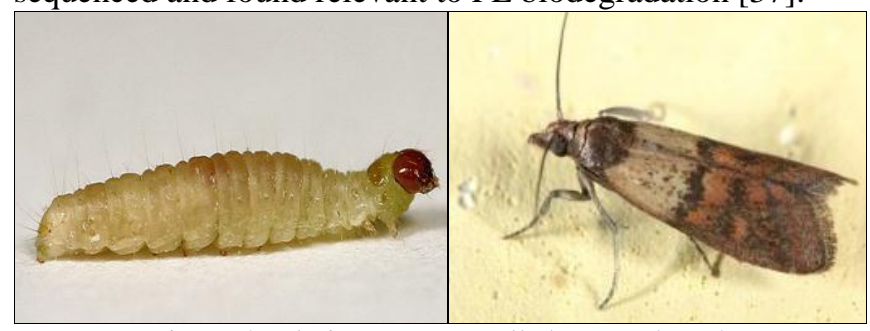

Figure 4: Plodia interpunctella larva and moth

Tenebrio molitor, also known as Darkling beetle, the larval form is called Yellow meal worm. Meal worms feed on stored food grains and are considered as pests. It was found that the Yellow meal worms could degrade Polystyrene [38] [39]. The larvae were fed with Styrofoam (a common PS product) as a sole diet and they survived as well as those fed with normal diet (bran). The degradation of PS was analyzed by using various analytical methods and isotopic tests. According to the study conducted by Yang et al., in a 16 day test period, $47.7 \%$ of the PS carbon was converted into $\mathrm{CO}_{2}$, indicating the degradation of PS [38]. Exiguobacterium spp. strain YT2 was found in the gut of yellow meal worm. When 
the bacterial strain was incubated with PS film, a biofilm was formed after 28 days associated with a decrease in PS surface hydrophobicity [39].

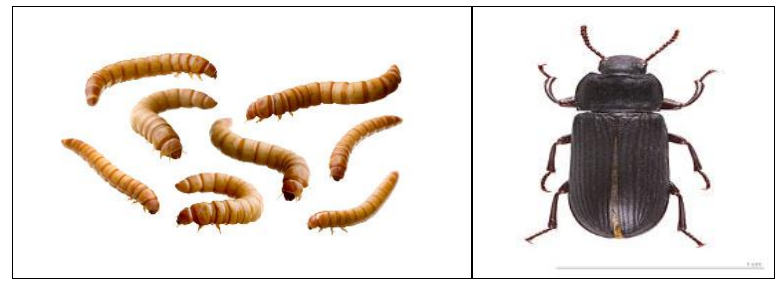

Figure 5: Tenebrio molitor larvae and adult

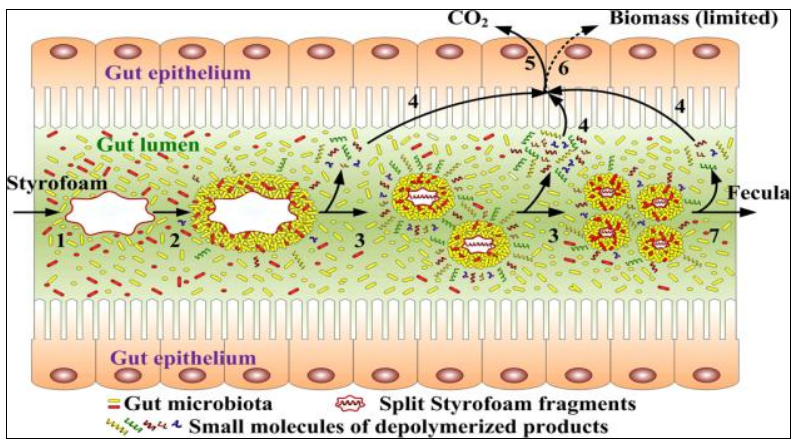

Figure 6: A proposed system for PS degradation in the gut of Tenebrio molitor larva. (Yang et al.) [39]

Galleria mellonella, also known as Greater wax moth is a serious pest in apiculture. Recently it was found that Galleria mellonella larvae could degrade polyethylene and convert it into ethylene glycol as an end product. The holes were formed when Galleria mellonella larvae were left in direct contact with PE. As reported, in 12 hours of time 100 larvae caused a mass loss of $92 \mathrm{mg}$ to the PE. After performing Atomic force microscopy, FTIR and TGA it was found that there was an obvious change in the topography of $\mathrm{PE}$ surface, formation of ethylene glycol and carbonyl bond on the homogenate treated area and 13\% of mass loss of PE over 14 hours of treatment respectively, indicating the sign of $\mathrm{PE}$ degradation [40].

Galleria mellonella being a serious pest of beehive naturally feed on beeswax. The adults lay their eggs in the beehive where the larvae grow eating beeswax. Chemically, beeswax is composed of lipid compounds, including alkanes, alkenes, esters and fatty acids [41]. Further investigations on the role of gut microorganisms and enzymes responsible for PE degradation need to be reported.

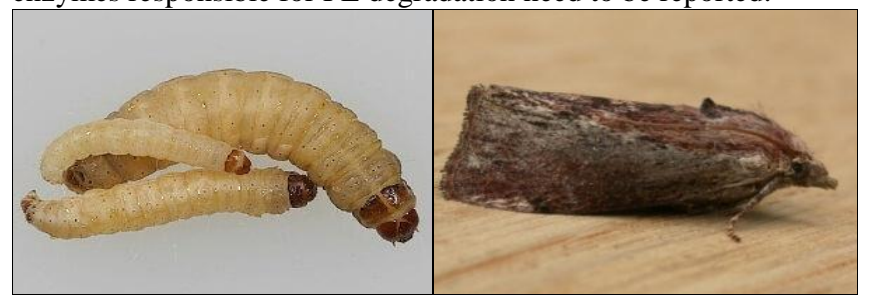

Figure 7: Galleria mellonella larvae and moth

\section{CONCLUSION}

The elimination of plastic pollution by developing new remediation methods could be helpful. Thermo- and photo-based pretreatments followed by microbial degradation reported till now have shown a very low efficiency in plastic degradation. Even though several microorganisms isolated from different areas have been reported till now practically, none of the organisms have found efficient. Recent approaches on plastic degradation by insects and their gut microorganisms have shown very interesting results. The gut microorganisms and digestive enzymes play an important role in overall physiological process of insects. However, molecular investigations on the entire physiological process of plastic degradation in the insect's gut need to be studied in detail and put an end to the plastic pollution concerns.

\section{REFERENCES}

[1]. F. R. Joel, "Introduction to Polymer Science”, Polymer Science and Technology, Prentice Hall PTR Inc., Upper Saddle River, New Jersey 07458, pp. 4-9, 1995.

[2]. M. Shimao, "Biodegradation of plastics", Current Opinion in Biotechnology, Vol. 12, Issue. 3, pp. 242-247, 2001.

[3]. Sivan A, "New perspectives in plastic biodegradation", Current Opinion in Biotechnology, Vol. 22 Issue. 3 pp. 422-426, 2011.

[4]. S. K. Ghosh, S Pal, S Ray, "Study of microbes having potentiality for biodegradation of plastics", Environmental Science and Pollution Research, Vol. 20, Issue. 7, pp. 43394355, 2013.

[5]. Fatimah Alshehrei, "Biodegradation of Synthetic and Natural Plastic by Microorganisms", Journal of Applied \& Environmental Microbiology, Vol. 5, Issue. 1, pp. 8-19, 2017.

[6]. McCarthy, S. P. "Plastics and the Environment", John Wiley and Sons, Anthony L. Andrady, New Jersey, pp. 359-377, 2003.

[7]. Kaserer, H. "Uber die Oxydation des Wasserstoffes und des Methans durch Mikroorganismen", Zentr. Bakt Parasitenk, Abt, Vol. 2, Issue. 15, pp. 573-576, 1906.

[8]. Sohngen,N.L. "Uber Baklerien Welche Methan als Kohlenstoff nahrung u.Ehergiequelle gebrauchen", Zentr Bakt Parasitcnk, Vol. 2, Issue. 15, pp. 513-517, 1906.

[9]. Bushnell, L. D. and Haas, H. F. “J. Bacteriology”, Vol. 41, pp. 653-673, 1941.

[10]. Ishigaki T, Sugano W, Nakanishi A, Tateda M, Ike M, Fujita M. 2004. "The degradability of biodegradable plastics in aerobic and anaerobic waste landfill model reactors". Chemosphere, Vol. 54, pp. 225-233, 2004.

[11]. Gu J-D., "Microbiological deterioration and degradation of synthetic polymeric materials: recent research advances", International Biodeterioration \& Biodegradation, Vol. 52, pp. 6991, 2003.

[12]. Y. Tokiwa, B. P. Calabia, C. U. Ugwu, S. Aiba, "Biodegradability of Plastics" International Journal of Molecular Science. Vol. 10, Issue. 9, pp. 3722-3742, 2009.

[13]. G. W. Fuhs, "Der mikrobielle Abbau von Kohlenwasserstoffen", Archiv für Mikrobiologie, Vol. 39, Issue. 4, pp. 374-422, 1961.

[14]. A. Starneckar, M. Menner, “Assessment of biodegradability of plastics under simulated composting conditions in a laboratory test system", International Biodeterioration \& Biodegradation, Vol. 37, Issue. 1-2, pp. 85-92, 1996.

[15]. J. D. Gu, T. E. Ford, D. B. Mitton, R. Mitchell, "Microbial corrosion of metals", The Uhlig Corrosion Handbook, 2nd Edition, New York Wiley, pp. 915-927, 2000.

[16]. S. K. Kale, A. G. Deshmukh, M. S. Dudhare, V. B. Patil, "Microbial degradation of plastic: a review", Journal of Biochemical Technology, Vol. 6 Issue. 2 pp. 952-961, 2015. 
[17]. R. Gautam, A. S. Bassi, E. K. Yanful, "A review of biodegradation of synthetic plastic and foams", Applied Biochemistry and Biotechnology, Vol. 141, Issue. 1, pp. 85-108, 2007.

[18]. Yamada-Onodera K, Mukumoto H, Katsuyaya Y, Saiganji A, Tani Y., "Degradation of polyethylene by a fungus, Penicillium simplicissimum $Y K$ ", Polymer Degradation and Stability, Vol. 72, pp. 323-327, 2001.

[19]. H. A. El-Shafei, N. H. El-Nasser, A. L. Kansoh, A. M. Ali, "Biodegradation of disposable polyethylene by fungi and Streptomyces species", Polymer Degradation and Stability Vol. 62, Issue. 2, pp. 361-365, 1998.

[20]. Vasile C. "Degradation and decomposition", Handbook of polyolefins: synthesis and properties, Marcel Dekker Inc., New York, 1993.

[21]. Tsuchii A, Suzuki T, Takahara Y, "Microbial Degradation of Styrene Oligomer", Agricultural and Biological Chemistry, Vol. 41, pp. 2417-2421, 1977.

[22]. Kaplan D, Hartenstein R, Sutter J, "Biodegradation of polystyrene, poly (metnyl methacrylate), and phenol formaldehyde”, Applied and Environmental Microbiology, Vol. 38, Issue. 3, pp. 551-553, 1979.

[23]. Lyklema J, Norde W, van Loosdrecht MCM, Zehnder AJB, "Adhesion of bacteria to polystyrene surfaces", Colloids and Surfaces 39, pp. 175-187, 1989.

[24]. Arutchelvi J, Sudhakar M, Arkatkar A, Doble M, Bhandari S, Uppara PV, "Biodegradation of Polyethylene and Polypropylene", Indian Journal of Biotechnology, Vol. 7, Issue. 1, pp. 9-22, 2008.

[25]. G. T. Howard, R. C. Blake, "Growth of Pseudomonas fluorescens on a polyester-polyurethane and the purification and characterization of a polyurethanase-protease enzyme" International Biodeterioration \& Biodegradation Vol. 42, Issue. 4, pp. 213-220, 1998.

[26]. D. Pečiulytė, "Microbial colonization and biodeterioration of plasticized polyvinyl chloride plastics. 2002.

[27]. S. Bonhomme et al. "Environmental biodegradation of polyethylene" Polymer Degradation and Stability, Vol. 81, Issue. 3, pp. 441-452, 2003.

[28]. Kathiresan, "Polythene and Plastics-degrading microbes from the mangrove soil", Revista de Biología Tropical, Vol. 51, Issue. 3-4, pp. 629-633, 2003.

[29]. S. Nanda, S. Sahu, J. Abraham, "Studies on the biodegradation of natural and synthetic polyethylene by Pseudomonas spp", Journal of Applied Sciences and Environmental Management, Vol. 14, Issue.2, pp. 57-60, 2010.

[30]. C. Abrusci et al. "Biodegradation of photo-degraded mulching films based on polyethylenes and stearates of calcium and iron as pro-oxidant additives", International Biodeterioration \& Biodegradation, Vol. 65, Issue. 3, pp. 451-459, 2011.

[31]. H. A. El-Shafei, N. H. El-Nasser, A. L. Kansoh, A. M. Ali, "Biodegradation of disposable polyethylene by fungi and Streptomyces species", Polymer Degradation and Stability Vol. 62, Issue. 2, pp. 361-365, 1998.

[32]. S. Webb et al. "Fungal Colonization and Biodeterioration of Plasticized Polyvinyl Chloride", American Society for Microbiology, Vol. 66, Issue. 8, pp. 3194-3200, 2000.

[33]. G. Saucedo-Castañeda, M. Gutiérrez-Rojas, A. Manzur, E. Favela-Torres, "Thermally treated low density polyethylene biodegradation by Penicillium pinophilum and Aspergillus niger" Journal of applied polymer science, Vol. 83, Issue. 2, pp. 305-314, 2002.
[34]. A. A. Shah, F. Hasan, A. Hameed, S. Ahmed, "Biological degradation of plastics: A comprehensive review", Biotechnology Advances, Vol. 26, Issue. 3, pp. 246-265, 2008.

[35]. V. R. Kannan et al. "Biodegradation of HDPE by Aspergillus spp. from marine ecosystem of Gulf of Mannar", Marine Pollution Bulletin, Vol. 96, Issue. 1-2, pp. 32-40, 2015.

[36]. J. Yang, Y. Yang, Wei-Min Wu, J. Zhao, L. Jiang, "Evidence of Polyethylene Biodegradation by Bacterial Strains from the Guts of Plastic-Eating Waxworms", Environment Science and Technology, Vol. 48, Issue. 23, pp. 13776-13784, 2014.

[37]. Y. Yang, J. Chen, Wei-Min. Wu, J. Zhao, J. Yang, "Complete genome sequence of Bacillus sp. YP1, a polyethylene-degrading bacterium from waxworm's gut", Journal of Biotechnology, Vol. 200, Issue. 20, pp. 77-78, 2015.

[38]. Yang et al., "Biodegradation and Mineralization of Polystyrene by Plastic-Eating Mealworms: Part 1. Chemical and Physical Characterization and Isotopic Tests", Environment Science and Technology, Vol. 49, Issue. 20, pp. 12080-12086, 2015.

[39]. Yang et al., "Biodegradation and Mineralization of Polystyrene by Plastic-Eating Mealworms: Part 2. Role of Gut Microorganisms", Environment Science and Technology, Vol. 49, Issue. 20, pp. 12087-12093, 2015.

[40]. P. Bombelli, C. J. Howe, F. Bertocchini, "Polyethylene biodegradation by caterpillars of the wax moth Galleria mellonella", Current biology, Vol. 27, Issue. 8, pp. R292-R293, 2017.

[41]. M. Maia, F. M. Nunes, "Authentication of beeswax (Apis mellifera) by high-temperature gas chromatography and chemometric analysis", Food Chemistry Vol. 136, Issue. 2, pp. 961-968, 2015.

\section{AUTHORS PROFILE}

Mr. Sheetal S Kesti obtained his M.Sc. in 2016 from Karnatak University, Dharwad and currently pursuing his Ph.D. in the Department of Biotechnology and Microbiology, Karnatak University Dharwad under the guidance of Dr. Shivasharana C. T. His main research work focuses on Entomology, Insect Gut Microbiology and Symbiosis, Diversity of Insects and Insect Molecular Biology and Biotechnology.

Dr. Shivasharana C. T. obtained his M.Sc. (2000), M.Phil (2001), and Ph.D (2005) from Department of Biotechnology, Gulbarga University, Kalburgi. $\mathrm{He}$ is currently working as an Assistant Professor in the Department of Biotechnology and Microbiology, Environment and Sustainable Technology Laboratory, Karnatak University

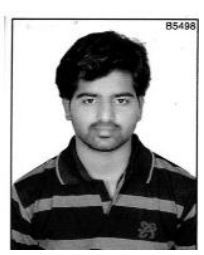
Dharwad. He has successfully guided 2 Ph.D. students and presently 8 students are working under his guidance. He has 18 research papers and 4 book chapters. He has attended more than 50 national and international conferences and workshops. His research areas are Enzymology, Algal Biotechnology and Environmental Biotechnology. 